\title{
Study on the Influencing Factors of Hotel Customer Satisfaction
}

\author{
Mingming Weng \\ Xiamen University Tan kah Kee College, Fujian,China \\ kmji@163.com
}

Keywords: Customer Satisfaction, Grey System Theory, Influencing Factors.

Abstract. The purpose of this study is to find out the most critical factors that affect the satisfaction degree of customers in Xi'an Hotel. This paper put forward the view that customer satisfaction was mainly influenced by the factors of service quality, price, product quality, brand and prestige. Then a survey of customers' satisfaction was administered and evaluated using grey correlation analysis technique. It was found out that 'Service Quality', 'Price', 'Product Quality', in order of importance, were the three most influential factors in determining customers' overall satisfaction levels. Finally, suggestions were developed for hotel managers.

\section{Introduction}

In today's competitive business environment, the ability to identify profitable customers, build their long-term loyalty and steadily expand existing relationships is key competitive factors to a hotel. To meet these factors, hotel managers regard monitoring customer satisfaction as one of the most important goals of a hotel for customer dissatisfaction is the overwhelming reason why customers leave a hotel. The factors driving customer satisfaction, however, are ambiguous and disputed. Therefore, managers of the hotel need to know the most influential factors and make effective decisions.

\section{Literature Review}

Measuring customer satisfaction is an integral part of the effort that improves a product's quality, resulting in a company's competitive advantage (Cravens et al.,1988;Garvin,1991). Oliver (1981) introduced the expectancy-disconfirmation model for studies of customer satisfaction in the retail and service industry. Expectancy-disconfirmation theory posits that customers form their satisfaction with a target product or service as a result of subjective (or direct) comparisons between their expectations and perceptions. Customers are directly asked to provide their perceptions or evaluations of the comparisons, using a "worse than /better than expected" scale. The resulting perceptions are conceptualized as a psychological construct called "subjective disconfirmation". The expectancy-disconfirmation model asserts that customer satisfaction is a direct function of subjective disconfirmation. That is, the size and direction of disconfirmation determine, in part, the level of satisfaction, when "confirmation" occurs, customers are believed to remain neither satisfied nor dissatisfied. Both expectations and perceptions also have been found to influence customer satisfaction and subjective disconfirmation under various circumstances (Churchill and Surprenant,1982). The typical customer satisfaction survey collects data on the causal context of satisfaction, i.e. antecedents (e.g. perceived performance of various product attributes/service) and consequences (e.g. overall satisfaction level), repurchase intentions and word-of-mouth intentions).According to the Satisfaction-Profit Chain principle(Anderson \& Mittal,2000), improving product and service attributes causes increased customer satisfaction, increased customer satisfaction leads to greater customer retention and improving customer retention greater profitability.

Recent studies, nevertheless, support the notion that customer satisfaction can be measured from the perspective of performance evaluations, making the inclusion of the disconfirmations process unnecessary (Olshavsky and Miller,1972);Churchill and Suprenant,1982;Cronin and Taylor ,1992). 
Their studies of consumer behavior emphasize that customer satisfaction remains a concern in the post-purchase period (Westbrook and Oliver ,1991).

However, the development of measurement instruments of service quality and customer satisfaction and the subsequent research dialogue regarding the appropriateness of these instruments is far from conclusive (Cronin and Taylor ,1992;Parasuraman, Zeithaml, and Berry, 1992). The strong effect of context and content of application, however, leaves little leverage for universal measures of service quality and satisfaction. What remains therefore, is not for any measurement instrument to be positioned in view of existing literature but also to be differentiated in order to be able to adapt to different business environments. This reflects the position of Brown, Churchill, and Peter (1993).

\section{Purpose of the Study}

The purpose of the study is to determine the primary factors driving customer satisfaction which heightens customer loyalty and prevents customer churn, lowers customers' price sensitivity, reduces the costs of failed marketing and of new customer creation, reduces operating costs due to customer number increases, improves the effectiveness of advertising, and enhances business reputation(Fornell ,1992). Different researchers separated the components of customer satisfaction and hotel managers usually don't know which factors are most influential. It is therefore essential for hoteliers to understand the relationship between customers' levels of satisfaction towards hotel factors which have different importance.

\section{Methodology}

Grey correlation analysis. Grey correlation analysis is one important method of Grey system theory to study the correlation. The method has an advantage of studying small imprecise sample which can analyze the uncertain relationship between evaluating object and influencing factors. Based on the grey correlation analysis method, this study tries to find the primary factors which drive hotel customers' satisfaction. Specific steps of the analysis are as follows.

1. Decide the comparative sequence (evaluating objects) and the standard sequence (evaluating indicators).Suppose the number of evaluating objects and evaluating indicators is respectively $\mathrm{m}$ and $\mathrm{n}$. So the comparative sequence $\left(\mathrm{X}_{\mathrm{i}}\right)$ and standard sequence $\left(\mathrm{X}_{0}\right)$ are as follows.

$$
\begin{aligned}
& X_{\mathrm{i}}=\left\{\mathrm{X}_{\mathrm{i}}(\mathrm{k}), \mathrm{k}=1,2, \ldots, \mathrm{n}\right\} \quad(\mathrm{i}=1,2, \ldots, \mathrm{m}) \\
& \mathrm{X}_{0}=\left\{\mathrm{X}_{0}(\mathrm{k}), \mathrm{k}=1,2, \ldots, \mathrm{n}\right\}
\end{aligned}
$$

2. Calculate the grey related coefficient $(\varepsilon)$.

$$
\varepsilon_{i}(k)=\frac{\min _{i} \min _{k}\left|X_{0}(k)-X_{i}(k)\right|+\xi \max _{i} \max _{k}\left|X_{0}(k)-X_{i}(k)\right|}{\left|X_{0}(k)-X_{i}(k)\right|+\xi \max _{i} \max _{k}\left|X_{0}(k)-X_{i}(k)\right|}
$$

3. Calculate the grey related degree $\left(\mathrm{r}_{\mathrm{i}}\right)$.

$$
r_{i}=\frac{1}{n} \sum_{k=1}^{n} \varepsilon_{i}(k)
$$

4. According to the grey related degree, find out which factor is primarily effective and which one is secondary.

Sample.The study people consisted of two hundred and forty (240) customers in eight upscale hotels in xi'an city, a famous ancient city which is the political, economic and cultural centre of ShanXi province. The questionnaire used consisted of opinion questions regarding the satisfaction levels as 
well as information-gathering questions regarding the score of each factor. A 15-point scale was used( $1=$ badly satisfy, $8=$ neutral, $15=$ strongly satisfy). The second section consisted of background questions about demographic variables such as age, gender, and education. Finally, two hundred (200) actual questionnaires were analyzed by the study..

\section{Results}

Factors driving customer satisfaction are evaluated by customers in the eight upscale hotels. Table1 presents the score results of each factor.

Table 1 Score

\begin{tabular}{|l|l|l|l|l|l|}
\hline Hotel & Brand & $\begin{array}{l}\text { Service } \\
\text { Quality }\end{array}$ & Price & $\begin{array}{l}\text { Product } \\
\text { Quality }\end{array}$ & Prestige \\
\hline Hotel A & 10 & 12 & 12 & 8 & 10 \\
\hline Hotel B & 8 & 9 & 10 & 9 & 5 \\
\hline Hotel C & 4 & 6 & 4 & 8 & 6 \\
\hline Hotel D & 12 & 6 & 10 & 11 & 12 \\
\hline Hotel E & 10 & 10 & 8 & 6 & 8 \\
\hline Hotel F & 10 & 11 & 10 & 7 & 9 \\
\hline Hotel G & 9 & 8 & 9 & 10 & 8 \\
\hline Hotel H & 6 & 7 & 7 & 8 & 8 \\
\hline
\end{tabular}

We can see from the table that the hotel A got 12-point on 'Service Quality' which is her highest score and the hotel B got her highest score 10-point on 'Price'. The rest may be deduced by analogy, so we can get the standard sequence $X_{0}$ which is shown in Table 2 .

Table 2 Standard sequence $\left(X_{0}\right)$ and Comparative sequence

\begin{tabular}{|l|l|l|l|l|l|l|l|l|}
\hline & 1 & 2 & 3 & 4 & 5 & 6 & 7 & 8 \\
\hline$\left(\mathrm{X}_{0)}\right.$ & 12 & 10 & 8 & 12 & 10 & 11 & 10 & 8 \\
\hline Brand $\left(\mathrm{X}_{1}\right)$ & 10 & 8 & 4 & 12 & 10 & 10 & 9 & 6 \\
\hline $\begin{array}{l}\text { Service } \\
\text { Quality }\left(\mathrm{X}_{2)}\right.\end{array}$ & 12 & 9 & 6 & 6 & 10 & 11 & 8 & 7 \\
\hline Price $\left(\mathrm{X}_{3)}\right.$ & 12 & 10 & 4 & 10 & 8 & 10 & 9 & 7 \\
\hline $\begin{array}{l}\text { Product } \\
\text { Quality }\left(\mathrm{X}_{4}\right)\end{array}$ & 8 & 9 & 8 & 11 & 6 & 7 & 10 & 8 \\
\hline Prestige $\left(\mathrm{X}_{5}\right)$ & 10 & 5 & 6 & 12 & 8 & 9 & 8 & 8 \\
\hline
\end{tabular}

According to the grey correlation analysis method, we analyzed and compared the score step by step. Then got Table 3 and Table 4.

Table 3

\begin{tabular}{|l|l|l|l|l|l|l|l|l|}
\hline & 1 & 2 & 3 & 4 & 5 & 6 & 7 & 8 \\
\hline$\Delta_{1}=\left|x_{0}(k)-x_{1}(k)\right|$ & 2 & 2 & 4 & 0 & 0 & 1 & 1 & 2 \\
\hline$\Delta_{2}=\left|x_{0}(k)-x_{2}(k)\right|$ & 0 & 1 & 2 & 6 & 0 & 0 & 2 & 1 \\
\hline$\Delta_{3}=\left|x_{0}(k)-x_{3}(k)\right|$ & 0 & 0 & 4 & 2 & 2 & 1 & 1 & 1 \\
\hline$\Delta_{4}=\left|x_{0}(k)-x_{4}(k)\right|$ & 4 & 1 & 0 & 1 & 4 & 4 & 0 & 0 \\
\hline$\Delta_{5}=\left|x_{0}(k)-x_{5}(k)\right|$ & 2 & 5 & 2 & 0 & 2 & 2 & 2 & 0 \\
\hline
\end{tabular}

$\min _{i} \min _{k}\left|X_{0}(k)-X_{i}(k)\right|=0$

$\max _{i} \max _{k}\left|X_{0}(k)-X_{i}(k)\right|=6$ 


$$
\varepsilon_{i}(k)=\frac{0+0.5 * 6}{\left|x_{0}(k)-x_{i}(k)\right|+0.5 * 6}=\frac{3}{\Delta_{i}(k)+3}
$$

Table 4 Grey related coefficient

\begin{tabular}{|l|l|l|l|l|l|l|l|l|}
\hline & 1 & 2 & 3 & 4 & 5 & 6 & 7 & 8 \\
\hline$\varepsilon_{1}(k)$ & 0.6 & 0.6 & 0.43 & 1 & 1 & 0.75 & 0.75 & 0.6 \\
\hline$\varepsilon_{2}(k)$ & 1 & 0.75 & 0.6 & 0.33 & 1 & 1 & 0.6 & 0.75 \\
\hline$\varepsilon_{3}(k)$ & 1 & 1 & 0.43 & 0.6 & 0.6 & 0.75 & 0.75 & 0.75 \\
\hline$\varepsilon_{4}(k)$ & 0.43 & 0.75 & 1 & 0.75 & 0.43 & 0.43 & 1 & 1 \\
\hline$\varepsilon_{5}(k)$ & 0.6 & 0.375 & 0.6 & 1 & 0.6 & 0.6 & 0.6 & 1 \\
\hline
\end{tabular}

Using the expressions, the grey related degree which indicates the relationship between customer satisfaction and influencing factors is calculated.

$$
\begin{aligned}
& r_{1}=\frac{1}{8} \sum_{i=1}^{8} \varepsilon_{1}(k)=\frac{1}{8}\left(\varepsilon_{1}(1)+\varepsilon_{1}(2)+\varepsilon_{1}(3)+\varepsilon_{1}(4)+\varepsilon_{1}(5)+\varepsilon_{1}(6)+\varepsilon_{1}(7)+\varepsilon_{1}(8)\right)=0.716 \\
& r_{2}=0.754, r_{3}=0.735, r_{4}=0.724, r_{5}=0.672
\end{aligned}
$$

The result shows us $r_{2}>r_{3}>r_{4}>r_{1}>r_{5}$. This indicates that hotel customers in xi'an pay more attentions to the service quality and their satisfaction levels are strongly effected by this factor. Afterwards, price and product quality are the secondary factors. The brand of the hotel is the fourth aspect customers cared about. Moreover, the prestige of the hotel has relatively small impacts on customer satisfaction.

\section{Conclusions}

This study has identified the five hotel factors, which are deemed important to customers. The five hotel factors are: 'Brand', 'Price', 'Product Quality', 'Service Quality' and 'prestige'. Out of these hotel factors, 'Service Quality' and 'Price' are considered to be the top two factors that determined customers' overall satisfaction with hotels in Xi'an.

As 'Service Quality' has been identified as the most influential factor, it appears that hotel customers nowadays are not only looking for basic services and facilities provided by a hotel ,but also are expecting a high standard of personal service. Hoteliers should ensure the quality of hotel services by constantly reviewing their customers' needs, and by strengthening customer service training programs for their employees. Internal marketing is also crucial to the quality of hotel services. That is, treating employees as internal customers would enhance the employees' satisfaction, which is fundamental to the provision of good service to the hotel customers(Heung et al.,1996).Other hotel factors such as 'Brand', 'Price', 'Product quality' and 'Prestige' should not be ignored. Although this study finds that these hotel factors are found to be less important in influencing travelers' overall satisfaction levels, hoteliers should maintain the standards of these services and facilities to meet the basic needs of the customers. Hoteliers should be aware that even though these factors are not the central factors leading to customer satisfaction and repeat patronage, the absence or failure of these factors to meet customers' desires could result in their dissatisfaction.

Our findings are considered useful to the hotel industry as they provide a clear indication on how to improve their service provisions in the Xi'an hotel industry. Once the hotel attributes in relation to customers' requirements are clearly identified and understood, hotel managers are more likely to be able to anticipate and cater for their customers' desires and needs, rather than merely reacting to their dissatisfaction(Oberoi and Hales, 1990)

On the other hand, this study has some limitations. There are other factors influencing customer satisfaction, apart from suggested in this study, such as value, security, and general amenities. In order 
to remedy these limitations, future studies could examine some of the following factors. In addition, in order to identify more methodically the factors influencing customer satisfaction, hotel industry must be compared with other industries.

\section{References}

[1] A.D. Athanassopoulos, 2000. Customer satisfaction cues to support market segmentation and explain switching behavior. Journal of Business Research47,191-270

[2] Fornell, C., 1992. A national customer satisfaction barometer : the Swedish experience. Journal of Marketing 56,6-21

[3] Heung, V.C.S., Mok, C., Kwan, A., 1996. Brand loyalty in hotels: an exploratory study of overseas visitors to Hong Kong. Australian Journal of Hospitality Management 3 (1), 1-11

[4] H. Oh, 1999. Service quality, customer satisfaction, and customer value: A holistic perspective. Hospitality Management 18,67-82

[5] Hunt, J.D.,1975. Image as a factor in tourism development. Journal of Travel Research 13, 3-7.

[6] J.H. Lee, S.C. Park, 2005. Intelligent profitable customers segmentation system based on business intelligence tools. Expert Systems Application29,145-152.

[7] J.L. Deng, 1987.The basic methods of Grey system theory. Central China technical university publication , 19-28.

[8] M.-K. Kim, M.-C. Park, D.-H. Jeong, 2004.The effects of customer satisfaction and switching barrier on customer loyalty in Korean mobile telecommunication services. Telecommunications Policy 28, 145-159

[9] Oberoi, U., Hales, C.,1990. Assessing the quality of the conference hotel service product: towards an empirically based model. The Service Industries Journal 10 (4), 700-721.

[10] Oh, H., Parks, S.C.,1997. Customer satisfaction and service quality: a critical review of the literature and research implications for the hospitality industry. Hospitality Research Journal 20(3), 35-64.

[11] Oliver, R.L.,1981. Measurement and evaluation of satisfaction processes in retail settings. Journal of Retailing 57, 25-48.

[12] T. Y. Choi, R. Chu, 2001.Determinants of hotel guests' satisfaction and repeat patronage in the Hong Kong hotel industry. Hospitality Management 20,279-281 